\title{
INTERDISCIPLINARY INTERACTION IN MAINTAINING THE REPRODUCTIVE HEALTH IN WOMEN WITH UTERINE LEYOMYOMA
}

DOI: 10.36740/WLek202105120

\author{
Iryna Yu. Karacharova' ${ }^{1}$, Tetiana M. Kozarenko ${ }^{2}$, Maya A. Flaksemberg ${ }^{3}$, Alla G. Kornatska ${ }^{3}$, \\ Valentyna K. Kondratiuk ${ }^{3,4}$, Iryna M. Nikitina ${ }^{5}$ \\ 1NUCLEAR MEDICINE CENTER OF KYIV CITY CLINICAL CANCER CENTER, KYIV, UKRAINE \\ ${ }^{2}$ INSTITUTE OF NUCLEAR MEDICINE AND DIAGNOSTIC RADIOLOGY OF THE NAMS OF UKRAINE, KYIV, UKRAINE \\ ${ }^{3}$ STATE INSTITUTION «INSTITUTE OF PEDIATRICS, OBSTETRICS AND GYNECOLOGY NAMED AFTER ACADEMICIAN OM LUKYANOV ACADEMY OF MEDICAL \\ SCIENCES OF UKRAINE», KYIV, UKRAINE \\ ${ }^{4}$ SHUPYK NATIONAL HEALHCARE UNIVERSITY OF UKRAINE, KYIV, UKRAINE \\ 5SUMY STATE UNIVERSITY, SUMY, UKRAINE
}

\begin{abstract}
The aim: 0ptimizing the interdisciplinary approaches in the diagnosis and monitoring the dynamics of uterine leiomyoma treatment by high-intensity focused ultrasound ablation. Materials and methods: In the course of scientific research we conducted a survey 72 women of reproductive age were diagnosed with leiomyoma. All patients underwent bimanual gynecological examination, ultrasound and MRI to determine the condition of the pelvic organs, assess the structure, location, number of myomas, as well as assess the possible acoustic pathway of high-intensity focused ultrasound. During monitoring, dynamic contrasting was used to determine the zone of node necrosis. Methods of control in the postoperative period: ultrasound, MRI of the pelvic organs using paramagnetic, were performed after 1, 3, 6 months. Ultrasound ablation of uterine fibroids was performed using the JC extracorporeal treatment system (Chongqing HAIFU (HIFU) Technology Co. Ltd., China) with a built-in ultrasound system (Italy).

Controlling the direct result was based on gray scale changes during real-time ultrasound examination on the monitor of the JC device. Since HIFU is a non-invasive method of treatment, in the future, the diagnosis was limited to using the ultrasound and MRI paramagnetic. Indicators such as: uterine body size were considered as indicators that characterize the effectiveness of treatment; specific volume of myoma; regression of uterine body size; regression of the myoma; regression of the node, calculated on its specific volume, because one patient could have several nodes.

Results: Analyzing the obtained results, it should be noted that for a month the average volume of leiomatous hives that were exposed to HIFU, almost did not change and was $122 \mathrm{~cm}^{3}$, while three months after treatment it was $-98 \mathrm{~cm}$. The nodes underwent a significant reduction 6 months after the treatment, their volume averaged $61 \mathrm{~cm}^{3}$. The dynamics analysis results of uterine body volume reduction, which is no less important expected result, showed the following: in the first month after the intervention the uterine volume almost did not change and, compared to the average size before treatment $342 \mathrm{~cm}^{3}$, was $300 \mathrm{~cm}^{3}$. In three months after treatment, the body volume of the uterus decreased to $264 \mathrm{~cm}^{3}$, and in six months - to $200 \mathrm{~cm}^{3}$.

When assessing the node 6 months after the procedure, it was found that during this period there was a significant reduction in the volume of leiomyoma, which was positively correlated with the clinical manifestations of the disease.

Conclusions: An interdisciplinary approach with the widespread introduction of modern organ-preserving techniques is an important direction in maintaining the reproductive health of women with uterine leiomyoma.

Positive dynamics of leiomatous node volume regression depends on its location, volume and MR type. The terms 1 and 3 months after ultrasound ablation are insufficient for objective radiological evaluation of the treatment outcome, but are important for the choice of further tactics in observing and treating the uterine leiomyoma.
\end{abstract}

KEY WORDS: ultrasonic ablation, uterine leiomyoma, hysterectomy, uterine fibroids

Wiad Lek. 2021;74(5):1152-1157

\section{INTRODUCTION}

In modern conditions, one of the most important and urgent tasks of gynecology is the preserving women's reproductive health. The normal functioning of the female reproductive system is considered to be one of the most important indicators of public health as a whole. Uterine fibroids are the most common benign tumor among all female genital tumors diagnosed in women under the age of 50 and are the leading indication for hysterectomy $(39 \%$ of cases) $[1,2]$.
Due to the prevalence of uterine leiomyoma, preserving the reproductive function in this group of women acquires great social significance. This is due to the tendency to increase the average age of women planning their first pregnancy, when the possibilities of reproductive function are quite limited. Uterine leiomyoma is a common cause of decreased fertility in women of reproductive age. Therefore, every year the number of patients is growing who, in order to achieve the desired pregnancy, require using a wide range of modern organ-preserving techniques 
based on multidisciplinary interaction of gynecologists and radiologists $[3,4]$.

The tactics of therapeutic measures for uterine leiomyoma should be individualized and based on the analysis of clinical and anamnestic data (age, ovarian reserve, reproductive plans, take into account the presence of other causes of infertility), topographic and anatomical features (myoma location, size, number of nodes), and to take into account the possible risks and consequences of the intervention (intra- and postoperative complications, complications of pregnancy and childbirth) [5-7].

High intensity focused ultrasound (HIFU) is a term describing the therapeutic use of focused high intensity ultrasound waves, which is a completely non-invasive technique distinguishing it from other treatments of uterine fibroids and explaining the interest of the scientific community in it, research and widespread implementation in various fields of medical practice $[7,8]$.

Since the appearance of the first industrial plants, hundreds of thousands of patients with neoplasms of the prostate, liver, pancreas, mammary glands, brain, and uterine fibroids have been treated by ultrasound ablation. According to The Focused Ultrasound Foundation, there are currently more than 200 HIFU research centers worldwide. The main indication, (41\% of all cases; 89353 interventions), for using the focused ultrasound is uterine leiomyoma [9].

The fundamental physical mechanism of high-intensity focused ultrasound ablation is the absorption of ultrasonic waves and their conversion into heat which was first described in 1972 [10].

The therapeutic effect of the method is achieved due to the three main mechanisms of focused ultrasound damaging effects: thermal ablation, acoustic cavitation and damage to the smallest vessels. The success of ultrasound ablation directly depends on the accuracy of ultrasound examining the women before the procedure. Comprehensive radiological diagnosis includes assessment of the location, size, number, structure and features of vascularization of uterine leiomyoma, followed by the development of a detailed treatment plan. That is why there is a need to improve the approach to sonography and magnetic resonance imaging of uterine fibroids [7-11].

When analyzing the research results of various authors' teams, attention is drawn to the lack of common views in the world scientific community regarding performance criteria (ovarian function, sexual function, quality of life, etc.), the frequency of re-examinations and their methodology [12-16, 18].

The cited literature data indicate the relevance of studying the features of uterine fibroids ultrasound ablation. Due to the prevalence of pathology, especially among women of reproductive age, this technique of organ-preserving non-invasive treatment can potentially be shown to many patients. Individualization of indicating and determining the place and role of ultrasound ablation as an independent method and in the combined treatment of uterine fibroids require further research.

\section{THE AIM}

Optimizing the interdisciplinary approaches in the diagnosis and monitoring the dynamics of uterine leiomyoma treatment by high-intensity focused ultrasound ablation.

\section{MATERIALS AND METHODS}

In order to evaluate the effectiveness of uterine leiomyoma organ-preserving treatment by using the method of high-intensity focused ultrasound ablation, substantiation of the diagnostic algorithm of primary examining and monitoring these patients to evaluate the effectiveness of treatment, 72 women of reproductive age were diagnosed with leiomyoma. The average age of women who underwent the procedure was $34 \pm 4$ years. All procedures were carried out in accordance with the ethical standards of the responsible committee on human experimentation and with the Helsinki Declaration of 1975, as revised in 2000.

Inclusion criteria were: established diagnosis of uterine fibroids; the patient's desire to preserve the uterus; high risk of surgical treatment; size $2-8 \mathrm{~cm}$ in diameter - for leiomatous nodes on the anterior wall; $3-8 \mathrm{~cm}$ in diameter on the back wall; absence of extra genital pathology in the stage of decompensation.

Exclusion criteria were: atypical endometrial hyperplasia, subserous myomas on a thin stalk; cervical nodes; lack of opportunity to choose a safe acoustic path; fibro-scar changes of the anterior abdominal wall; III-IV degree obesity; pregnancy, IUD; anesthetic contraindications.

All patients underwent bimanual gynecological examination, ultrasound and MRI to determine the condition of the pelvic organs, assess the structure, location, number of myomas, as well as assess the possible acoustic pathway of high-intensity focused ultrasound. The type of uterine leiomyoma was established according to the FIGO classification [17, 18]. Ultrasound was performed using a convex sensor with a frequency of $3.7 \mathrm{MHz}(\mathrm{C} 5-2)$ and a transvaginal sensor with a frequency of $7.5 \mathrm{MHz}(\mathrm{C} 8-4 \mathrm{~V})$ on a Philips HD11. Sufficient filling of the bladder (bladder volume not less than $300 \mathrm{ml}$ ) was mandatory for transabdominal examinations. This filling was considered to be optimal when the bladder covered the bottom of the uterine body. The condition of the transvaginal examination was emptied bladder.

Magnetic resonance imaging was performed on a tomograph with a high magnetic field strength (1.5T). The MRI protocol included the following sequences: T2-ZZ in the sagittal, axial and frontal planes, $\mathrm{T} 1-\mathrm{ZZ}$ in the axial plane, T2-ZZ fet set in the axial and frontal planes, DWI (b-50,1000), T1-ZZ fet set in the sagittal plane, T1-ZZ fet set in the sagittal, axial and frontal planes [19].

Depending on the intensity of the predominant $M R$ signal on T2-ZZ in relation to the myometrium and skeletal muscles, the following MR types of fibroids were distinguished: Type I - low intensity signal predominates on T2-ZZ, nodes in the form of black homogeneous for- 
mations. Type II - the signal of average or mixed intensity on T2-ZZ, knots in the form of gray formations prevails. Type III - dominated by high-intensity signal on T2VI, nodes in the form of white formations.

Measurements of the size of the uterus and myomas were performed in three orthogonal planes (length - anterior-posterior size - width) followed by hardware calculation of the corresponding volumes by the formula: $\mathrm{V}=0.52 \mathrm{x}$ $\mathrm{L} \times \mathrm{AP} \times \mathrm{W}$, where $\mathrm{V}$ is the volume, $\mathrm{cm} 3$; $\mathrm{L}$ - length, $\mathrm{cm}$; AP - anterior-posterior size, $\mathrm{cm}$; W - width, $\mathrm{cm} ; 0.52$ correction factor for oval objects, in particular, myomas.

During monitoring, dynamic contrasting was used to determine the zone of node necrosis. Methods of control in the postoperative period: ultrasound, MRI of the pelvic organs using paramagnetic, were performed after 1, 3, 6 months.

Ultrasound ablation of uterine fibroids was performed using the JC extracorporeal treatment system (Chongqing HAIFU (HIFU) Technology Co. Ltd., China) with a built-in ultrasound system (Italy).

Features of anesthesiological method support were ultrasonic ablation, complete immobilization of the patient, adequate sedation with the availability of elementary contact in conditions of general hypothermia and non-physiological position of the patient for a long time. Due to the above, multicomponent sedation was used.

Controlling the direct result was based on gray scale changes during real-time ultrasound examination on the monitor of the JC device. Since HIFU is a non-invasive method of treatment, in the future, the diagnosis was limited to using the ultrasound and MRI paramagnetic. To objectify the effect, monitoring terms of 1, 3 and 6 months after ablation were chosen. Indicators such as: uterine body size were considered as indicators that characterize the effectiveness of treatment; specific volume of myoma; regression of uterine body size; regression of the myoma; regression of the node, calculated on its specific volume, because one patient could have several nodes [20,21].

The preparation of data for analysis was carried out in Microsoft Excel, and statistical analysis of the data was carried out mainly using specialized software STATISTICA 64 ver.10.0.1011.0 firm StatSoft Inc.

\section{RESULTS}

According to the results of radio-diagnostic methods of examination (ultrasound, MRI) 47 patients with uterine leiomyoma were divided into groups according to MR-type and localization of leiomatous nodes (Tables 1-3).

The average specific volume of the leiomatous node before treatment was $131 \mathrm{~cm} 3$, the minimum specific size was $3.7 \mathrm{~cm} 3$, and the maximum was $522 \mathrm{~cm} 3$, respectively. Also in the dynamics of the study, we evaluated how during the changes in the size of leiomatous nodes changed the volume of the uterine body, which before treatment averaged $342 \mathrm{~cm}^{3}$.

When forming a group of patients for possible further ultrasound ablation of leiomatous nodes: the appro-
Table I. Distribution of leiomatous nodes according to the FIGO classification (abs,\%)

\begin{tabular}{cc}
\hline Type of leiomatous node & $\begin{array}{c}\text { the number of leiomatous } \\
\text { nodes }\end{array}$ \\
\hline Type $0,1,2$ & $7(9,8)$ \\
\hline Type 3 & $12(16,7)$ \\
\hline Type 4 & $31(43)$ \\
\hline Type 5 & $22(30,5)$ \\
\hline Total & $72(100)$ \\
\hline
\end{tabular}

Table II. Distribution of leiomatous nodes by MR-type (abs,\%)

\begin{tabular}{ccc}
\hline \multirow{2}{*}{$\begin{array}{c}\text { Type of leiomatous } \\
\text { node }\end{array}$} & \multicolumn{2}{c}{ The number of leiomatous nodes } \\
\cline { 2 - 3 } & abs & $\%$ \\
\hline MR-type 1 & 51 & 84,8 \\
\hline MR-type 2 & 21 & 15,2 \\
\hline
\end{tabular}

The total number of

72

Table III. Distribution of leiomatous nodes of the uterine body by localization

\begin{tabular}{ccc}
\hline \multirow{2}{*}{ Localization } & \multicolumn{2}{c}{ The number of leiomatous nodes } \\
\cline { 2 - 3 } & abs & $\%$ \\
\hline $\begin{array}{c}\text { The anterior wall of the } \\
\text { uterine body }\end{array}$ & 45 & 62,5 \\
\hline $\begin{array}{c}\text { The back wall of the } \\
\text { uterus }\end{array}$ & 27 & 37,5 \\
\hline \begin{tabular}{c} 
The total number of \\
\hline
\end{tabular} & 72 \\
\hline
\end{tabular}

priate radio-diagnostic exclusion criteria were used: sonographic signs - the presence of calcifications in the myomatous node; intensive vascularization during Doppler; MRI signs - MR type 3; combination of MRI and sonographic signs - according to FIGO classification type 6 , type 7 ; localization in the isthmus or projection of the bottom of the uterine body; size less than $3 \mathrm{~cm}$ on the posterior wall of the uterus; the size of the myoma is more than $8 \mathrm{~cm}$.

When performing sonography in the projection of the necrosis zone, the result of HIFU-exposure, visualized increase in echogenicity, lack of vascularization. The size of the myoma as a whole was assessed by ultrasound. All patients underwent MRI of the pelvic organs after the procedure. And if before the HIFU procedure the MRI results were informative without contrast enhancement, then after the treatment the intravenous administration of paramagnetic during the MRI was mandatory. (figure 1)

Only when performing MRI with a paramagnetic it was possible to assess NPV (necrosis zone). On T2-ZZ these zones are inhomogeneous, mainly hypo intensive MR signal. On T1ZZ we noted a hyper intensive MR signal, and after dynamic contrast on the periphery of the node inhomogeneous accumulation of paramagnetic. Mainly in the center of the stroma of the leiomatous node, an area with no accumulation of paramagnetic in the form of a zone of hypo intense signal with a clear outline was detected; this was precisely the zone of necrosis (NPV) (Figure 2). 


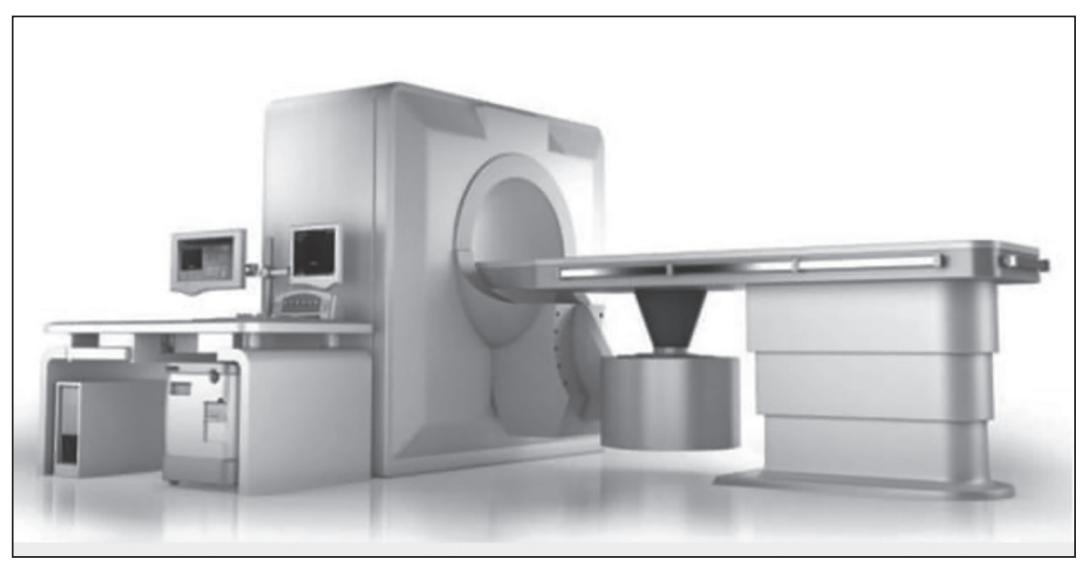

Fig. 1. General view of the system HIFU.

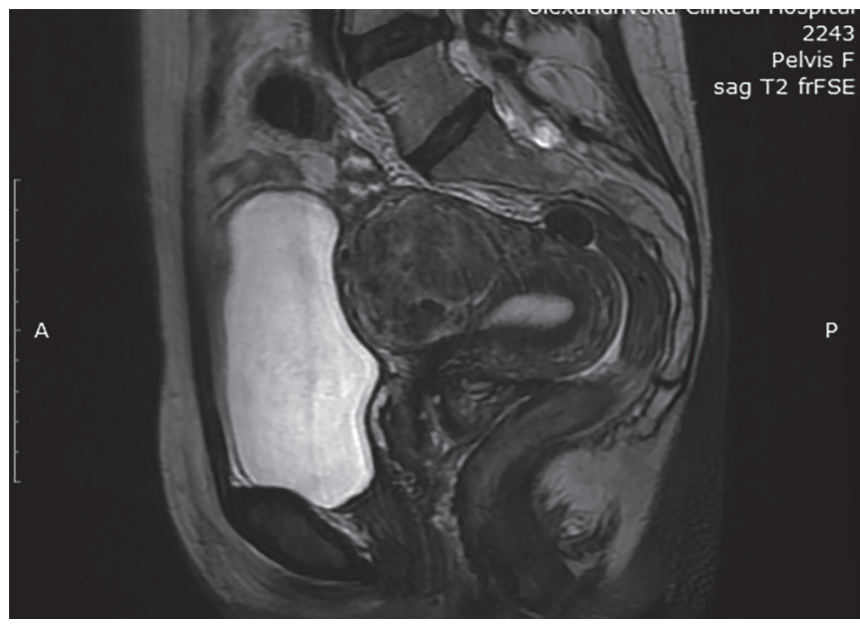

Fig. 2. magnetic resonance imaging of the pelvic organs, T2 - ZZ, sagittal projection. Leiomatous node of the uterine body before the procedure: 1 . leiomatous node; 2 . hyperintensive endometrium; 3 . the body of the uterus.

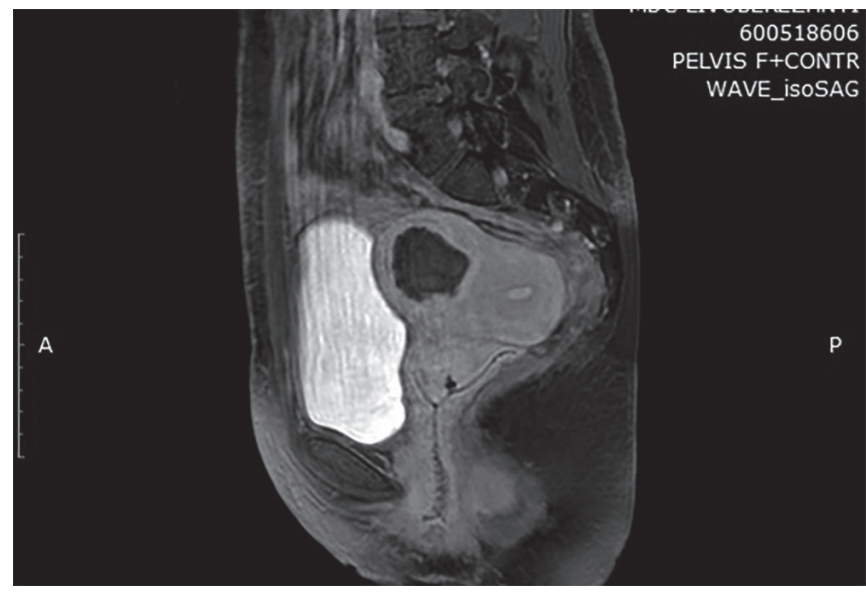

Fig. 3. MRl of the pelvic organs, T1 - ZZ using dynamic contrasting, sagittal projection. Leiomatous node of the uterine body after the procedure: a clearly formed area of necrosis in the projection of the myoma; hyperintensive endometrium, uterine body.

Table IV. Dynamics of regressive changes in leiomatous nodes and the uterine body as a result of HIFU exposure

\begin{tabular}{|c|c|c|}
\hline $\begin{array}{l}\text { Parameter } \\
\text { (month) }\end{array}$ & Medium & Median \\
\hline \multicolumn{3}{|c|}{ Specific volume of the node $\left(\mathrm{cm}^{3}\right)$} \\
\hline 1 st & $\begin{array}{c}122,4 \\
\mathrm{CI}[94,2 ; 150,5]\end{array}$ & 82,9 \\
\hline $3 s t$ & $\begin{array}{c}98,7 \\
\mathrm{CI}[74,9 ; 122,5]\end{array}$ & 61,9 \\
\hline $6 s t$ & $\begin{array}{c}61,1 \\
\mathrm{CI}[43,2 ; 78,5]\end{array}$ & 37,2 \\
\hline \multicolumn{3}{|c|}{ The specific volume of the uterine body } \\
\hline 1 st & $\begin{array}{c}300 \\
\text { CI[253,2;347] }\end{array}$ & 234,4 \\
\hline 3 st & $\begin{array}{c}264,5 \\
\text { CI[221;307,5] }\end{array}$ & 202,8 \\
\hline $6 s t$ & $\begin{array}{c}200,4 \\
\text { CI[167,8;233] }\end{array}$ & 143,9 \\
\hline
\end{tabular}

\section{DISCUSSION}

The dynamics of regressive changes of leiomatous nodes and the body of the uterus as a result of HIFU-exposure are presented in table 4.
The regression of uterine leiomyoma volume depended on the location, volume, and MR of the leiomatous node type. Analyzing the obtained results, it should be noted that for a month the average volume of leiomatous hives that 
were exposed to HIFU, almost did not change and was 122 $\mathrm{cm}^{3}$, while three months after treatment it was $-98 \mathrm{~cm} 3$. The nodes underwent a significant reduction 6 months after the treatment, their volume averaged $61 \mathrm{~cm}^{3}$ (Table IV).

The dynamics analysis results of uterine body volume reduction, which is no less important expected result, showed the following: in the first month after the intervention the uterine volume almost did not change and, compared to the average size before treatment $342 \mathrm{~cm}^{3}$, was $300 \mathrm{~cm}^{3}$. In three months after treatment, the body volume of the uterus decreased to $264 \mathrm{~cm}^{3}$, and in six months - to $200 \mathrm{~cm}^{3}$ (Table IV).

When assessing the node 6 months after the procedure, it was found that during this period there was a significant reduction in the volume of leiomyoma, which was positively correlated with the clinical manifestations of the disease.

\section{CONCLUSIONS}

An interdisciplinary approach with the widespread introduction of modern organ-preserving techniques is an important direction in maintaining the reproductive health of women with uterine leiomyoma. Criteria for exclusion of patients for ultrasound ablation of uterine leiomyoma: the presence of calcifications in the leiomatous node (sonographic signs); intensive vascularization (Doppler signs); MR type 3 leiomatous node (MRI signs); and leiomatous nodes type 6, type 7, localization of leiomatous nodes in the isthmus or projection of the bottom of the uterine body, the size of the leiomatous node is less than $3 \mathrm{~cm}$ on the posterior wall of the uterus, the size of the leiomatous node is more than $8 \mathrm{~cm}$.

Positive dynamics of leiomatous node volume regression depends on its location, volume and MR type. The terms 1 and 3 months after ultrasound ablation are insufficient for objective radiological evaluation of the treatment outcome, but are important for the choice of further tactics in observing and treating the uterine leiomyoma.

\section{REFERENCES}

1. Podol'skij V.V., Vovk I.B., Kornackaja A.G. Aktual'nye problemy reproduktivnogo zdorov'ja zhenshhin v Ukraine [Current problems of women's reproductive health in Ukraine]. Zdorov'e zhenshhiny. 2010; 4:121-6. (in Ukrainian).

2. Bujanova S.N., Mgeliashvili M.V., Petrakova S.A. Soremennye redstavlenija ob jetiologii, patogeneze i morfogeneze miomy matki [Modern ideas about the etiology, pathogenesis and morphogenesis of uterine fibroids]. Rossijskijvesnik akushera-ginekologa. 2008; 8(6): 45-51. (in Russian).

3. Styer A.K., Rueda B.R. The Epidemiology and Genetics of Uterine Best Pract. Res. Clin. Obstet. Gynaecol. 2016; 34:3-12.

4. Wise L.A., Laughlin-Tommaso S.K. Epidemiology of Uterine Fibroids: From Menarche to Menopause. Clin. Obstet. Gynecol. 2016;59(1):2-24.

5. Shapovalova A.I. Lejomioma matki i reprodukcija [Uterine leiomyoma and reproduction]. Zhurnal akusherstva izhenskih boleznej. 2019; 68(1): 93-101. (in Russian).

6. Kogan I.Ju., Bezhenar' V.F., Dolinskij A.K, Chmaro M.G. Jeffektivnost' vspomogatel'nyh metodov reprodukcii u bol'nyh s miomoj matki [Efficacy of assisted reproductive methods in patients with uterine fibroids]. Zhurnal akusherstva i zhenskih boleznej. 2012; 61(4): 113-18. (in Russian).
7. Dolinskij A.K. Rol' miomjektomii v preodolenii besplodija [The role of myomectomy in overcoming infertility]. Journal of Obstetrics and Women's Diseases. Zhurnal akusherstva i zhenskih boleznej. 2013; 62(1): 42-7. (in Russian).

8. Ji Y., Hu K., Zhang Y. et al. High-intensity focused ultrasound (HIFU) treatment for uterine fibroids: a meta-analysis. Arch Gynecol Obstet. 2017; 296(6): 1181-8.

9. Meshorer A., Prionas S.D., Fajardo L.F. et al. The effects of hyperthermia on normal mesenchymal tissues. Application of a histologic grading system. Arch Pathol Lab Med. 1983; 107(6): 328-34.

10. The Focused Ultrasound Foundation. 2017 https://www. fusfoundation.org.

11. ClinicalTrials.gov. 2017. https://clinicaltrials.gov/.

12. Nazarenko G.I., Krasnova T.V., Hitrova A.N. Vozmozhnosti jehografii v monitoringe i ocenke jeffektivnosti ul'trazvukovoj abljacii miomy matki [Possibilities of ultrasound in monitoring and evaluating the effectiveness of ultrasound ablation of uterine fibroids]. Ul'trazvukovaja i funkcional'naja diagnostika. 2012; 5: 39-52. (in Ukrainian).

13. Nazarenko G.I., Krasnova T.V., Hitrova A.N. et al. Opyt primenenija vysokointensivnogo fokusirovannogo ul'trazvuka pri lechenii miom matki [Experience in the use of high-intensity focused ultrasound in the treatment of uterine fibroids]. Ul'trazvukovaja i funkcional'naja diagnostika. 2012; 1: 41-51. (in Ukrainian).

14. Nazarenko G.I., Krasnova T.V., Tonkonogova I.V. et al. Ocenka jeffektivnosti bezopasnosti abljacii vysokointensivnym fokusirovannym ul'trazvukom (HIFU-abljacii) pri lechenii miomy matki v zavisimosti ot raspolozhenija uzlov [Evaluation of the effectiveness of ablation safety by high-intensity focused ultrasound (HIFU-ablation) in the treatment of uterine fibroids depending on the location of the nodes]. Ul'trazvukovaja i funkcional'naja diagnostika. 2016; 1:29-39. (in Ukrainian).

15. Nazarenko G.I., Krasnova T.V., Hitrova A.N., Kudrjavcev Ju.G. Vozmozhnosti vysokointensivnogo fokusirovannogo ul'trazvuka v lechenii miomy matki [Possibilities of high-intensity focused ultrasound in the treatment of uterine fibroids]. Medicinskaja vizualizacija. 2013; 1: 80-8. (in Ukrainian).

16. Nazarenko G.I., Hitrova A.N., Krasnova T.V., Episheva T.S. Vozmozhnosti ul'trazvukovoj abljacii miomy matki v povyshenii reproduktivnoj funkcii [Possibilities of ultrasound ablation of uterine fibroids in improving reproductive function]. Ul'trazvukovaja i funkcional'naja diagnostika. 2011; 1: 71-6. (in Ukrainian).

17. Munro M.G., Critchley H.O., Broder M.S., Fraser I.S. FIGO classification system (PALM-COEIN) for causes of abnormal uterine bleeding in nongravid women of reproductive age. FIGO working group on menstrual disorders. Int J Gynaecol Obstet. 2018; 113: 1-2.

18. Kozarenko T.M., Karacharova I.Ju., Goncharenko V.M, Kljusov 0.M. Ekstrakorporal'na abljacija miom tila matki visokointensivnim fokusovanim ul'trazvukom (HIFU) [Extracorporeal ablation of uterine fibroids by high-intensity focused ultrasound (HIFU)]. Aktual'ni problemi klinichnoï ta profilaktichnoï medicini. 2018; 2:77-85. (in Ukrainian).

19. Kozarenko T.M., Karacharova I.Ju., Goncharenko V.M. et al. Novi mozhlivosti u likuvanni miom tila matki - HIFU tehnologija. [New opportunities in the treatment of uterine fibroids - HIFU technology]. Zdorov'e zhenshhiny. 2017; 7(123):47-51. (in Ukrainian).

20. Gorban N.E., Vovk I.B., Nikitina I.M. et al. Immunoglobulin indicators to viruses cytomegal and genital herpes in the blood serum of women with non-atipical endometrial hyperproliferative pathology. Wiadomości Lekarskie, 2020;73 (8): 1600-5. 
21. Nikitina I.M., Smiyan S.A., Kondratiuk K.0. et al. Conditions of microelements exchange processes in women's placents in intrauterine infection of the fetus Wiadomości Lekarskie, 2020;73 (7): 1434-8.

The work is carried out within the framework of the research work "Optimization of diagnosis and prevention of diseases of the reproductive system and development of pathogenically grounded methods for their correction" (state registration number 011 U001801).

\section{ORCID and contributionship:}

Iryna Yu. Karacharova: 0000-0001-9015-0915 A, E,F

Tetiana M. Kozarenko: 0000-0002-0838-9773 ${ }^{B, D}$

Maya A. Flaksemberg: 0000-0002-7419-0180 B,D

Alla G. Kornatska: 0000-0001-6638-6426 D, F

Valentyna K. Kondratiuk: 0000-0001-6220-2116 A, D, F

Iryna M. Nikitina: 0000-0001-6595-2502 D, F, C

\section{Conflict of interest:}

The Authors declare no conflict of interest.

\section{CORRESPONDING AUTHOR}

Iryna M. Nikitina

Sumy State University

2 Rymskogo-Korsakova st., 40007 Sumy, Ukraine

tel:.+380662947360

e-mail:nikitina1med@gmail.com

Received: 21.12 .2020

Accepted:31.03.2021

A - Work concept and design, B - Data collection and analysis, C - Responsibility for statistical analysis,

D-Writing the article, $\mathbf{E}$-Critical review, $\mathbf{F}$ - Final approval of the article 